\title{
プロパン層流拡散火炎内の酸素濃度とすす粒子生成挙動の関係 *
}

\author{
座間 淑夫 ${ }^{* 1}$, 清水 一徳 ${ }^{* 2}$, 津久井 正樹 ${ }^{* 3}$, 古畑 朋彦 ${ }^{* 1}$, 新井 雅隆 ${ }^{* 4}$ \\ Relationship between $\mathrm{O}_{2}$ Concentration and Soot Formation \\ in Propane Laminar Diffusion Flame
}

\author{
Yoshio ZAMA*1 , Kazunori SHIMIZU, Masaki TSUKUI, Tomohiko FURUHATA and Masataka ARAI \\ ${ }^{* 1}$ Dept. of Mechanical System Engineering, Gunma Univ. \\ 1-5-1, Tenjincho, Kiryu, Gunma, 376-8515 Japan
}

\begin{abstract}
Oxygen $\left(\mathrm{O}_{2}\right)$ in a flame is one of the important substances for formation and oxidation of soot. Then it is necessary to investigate the effect of $\mathrm{O}_{2}$ concentration in a flame on soot formation for clarification of soot formation mechanism. In this study, soot formation and soot oxidation mechanism inside propane laminar diffusion flame were focused. $\mathrm{O}_{2}$ concentration of ambient air was adjusted as $21 \%$ and $18 \%$. Laser induced fluorescent (LIF) method and laser induced incandescent (LII) method were applied to measure $\mathrm{O}_{2}$ concentration and soot concentration distribution inside the flame. PM size distribution inside the flame was analyzed using scanning mobility particle sizer (SMPS). As the results, according to comparison between soot LII signal and $\mathrm{O}_{2}$ concentration along flame center, the LII signal was detected in a region of more than $2 \% \mathrm{O}_{2}$ concentration. It means that soot was not generated under $\mathrm{O}_{2}$ concentration less than $2 \%$. Inside the flame, number concentration of $\mathrm{PM}$ at $21 \% \mathrm{O}_{2}$ condition was larger than that at $18 \% \mathrm{O}_{2}$ condition. The difference of in-flame PM number concentrations between $18 \%$ and $21 \% \mathrm{O}_{2}$ conditions became small with increasing distance from a nozzle, and at outside of the flame, number concentration of PM at $21 \%$ $\mathrm{O}_{2}$ condition became smaller than that at $18 \% \mathrm{O}_{2}$ condition.
\end{abstract}

Key Words : Diffusion Combustion, Spectroscopic Measurement, Laser, $\mathrm{O}_{2}$ Concentration, LIF

\section{1. 緒言}

ディーゼル機関の燃焼排出ガス中には，すすなどからなるナノメーターサイズの粒子状物質（PM，Particulate Mater）やその前駆物質として考えられる多環芳香族炭化水素（PAHs, Polycyclic Aromatic Hydrocarbons）が含まれて おり，それらによる人体への悪影響が懸念されている(1). また，近年のディーゼル機関ではNOx の排出低減技術と して排気再循環(EGR)が取り入れられ，その結果，燃焼室内の酸素濃度が低くなり PM の生成挙動が変化すること が考えられる. したがって，周辺雰囲気の酸素濃度が低い場合の火炎内に形成されるナノ PM の生成挙動を把握す ることが重要である．燃焼により生成されるすすは燃料の不完全然焼が原因であることが知られており(2)，燃焼に 寄与する酸素はすすの生成に対して重要な支配因子である。そのため，火炎内の酸素濃度と然焼生成化学種の分析 を行った報告が多く存在する. Tuji ら (3)は，対向流拡散火炎に対して火炎内の燃焼ガス分析を行った．彼らは火炎 周辺の酸素が空気流や拡散により火炎帯に運ばれ，その一部は然料側に貫通することを明らかにしている。また火 炎帯を貫通した酸素は燃料の熱分解に寄与していることを示唆している．長谷川ら(4)は，酸素濃度が対向流拡散火 炎における PAHs の生成に及ぼす影響について調査している．Xu ら (5)は炭化水素を然料とした層流拡散火炎中のラ ジカル種 $(\mathrm{OH}, \mathrm{H}, \mathrm{O})$ と酸素濃度について計測を行なっている. これらの過去に行なわれた研究では，火炎内から然焼 ガスを直接サンプリングする手法を用いている．したがって然焼ガス中に含まれる化学種の分析の際，サンプリン

\footnotetext{
* 原稿受付 2012 年 11 月 20 日

*1 正員, 群馬大学大学院工学研究科 (

*2 群馬大学大学院工学研究科 (現 日野自動車 (株))

*3 群馬大学大学院工学研究科

$*_{4}$ 正員, フェロー, 群馬大学大学院工学研究科

E-mail: yzama@gunma-u.ac.jp
} 
グ用プローブ内での反応の失活が不完全であることが懸念される．このような懸念を排除するために著者らのグル ープでは，非接触計測法であるレーザを用いた光診断計測法を火炎内の酸素濃度を含む種々の化学種 $\left(\mathrm{NO}, \mathrm{OH}, \mathrm{O}_{2}\right.$ など)の濃度計測に適用してきた ${ }^{(6)}(8)$.

本研究では火炎の周囲酸素濃度を変化させて炭化水素系然料であるプロパン $\left(\mathrm{C}_{3} \mathrm{H}_{8}\right)$ を用いて層流拡散火炎を形成 し，形成した拡散火炎内の酸素濃度とす寸濃度分布をレーザ計測により計測した．またサンプリング法で得られた 火炎内で生成される PM 個数濃度分布と比較しながら, 火炎内酸素濃度がす寸粒子生成挙動に与える影響について 検討した.

\section{2. 実験装置}

\section{$2 \cdot 1$ 火炎形成装置}

本研究では直鎖系炭化水素燃料であるプロパンを用いて, 火炎高さ $L_{f}=30 \mathrm{~mm}$ の層流拡散火炎を形成した. 図 1 に 形成した火炎の概略を示す．内径 $6 \mathrm{~mm}$ の円筒ノズルから燃料を鉛直上方へ噴出し層流拡散火炎を形成した．拡散 火炎が形成される場合, 火炎周辺の酸素濃度は重要な支配因子である. 本研究の目的でもある酸素濃度 $21 \%$ EGR 燃焼を想定した $18 \%$ の雾囲気を形成寸るため, 火炎の周囲にシールドガスとして空気を流し, 酸素濃度 $18 \%$ の雾囲 気とする場合は, シールドガスを $\mathrm{N}_{2}$ ガスで希釈した。雾囲気の酸素濃度については, 酸素濃度計（XP-3180, COSMOS) を用いて測定した. 本研究では, 雾囲気酸素濃度 $\mathrm{O}_{2}$ amb に依らず火炎高さを $L_{f}=30 \mathrm{~mm}$ 一定としたため, 表 1 のように燃料流量が異なり， $\mathrm{O}_{2 \_a m b}=18 \%$ の燃料流量は $\mathrm{O}_{2 \_a m b}=21 \%$ に対して少ない. そのためノズル噴孔でのレ イノルズ数も異なることになる．また，雰囲気酸素濃度に依らず火炎先端が閉じた火炎であった．計測結果の表示 では火炎の中心軸を $z$ 軸, 半径方向を $r$ 軸とし, 円筒ノズルの出口中心にその原点を取った.

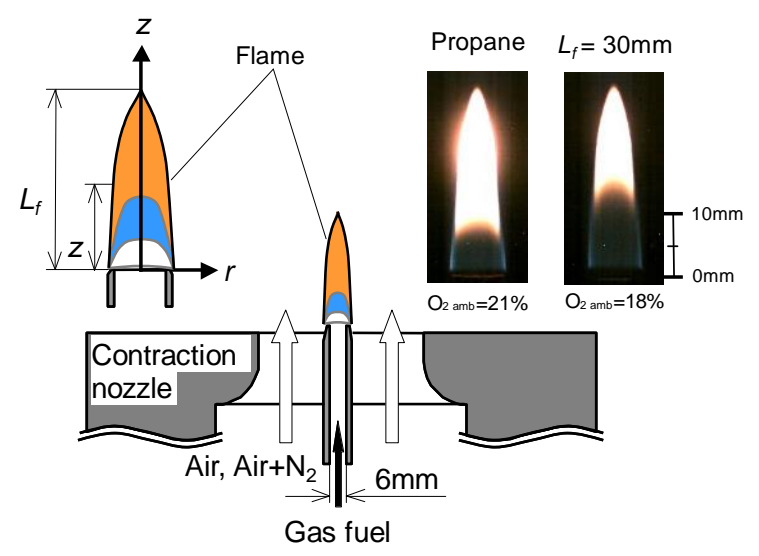

Table 1 Gaseous fuel jet condition

\begin{tabular}{|c|c|c|}
\hline Fuel & \multicolumn{2}{|c|}{ Propane $\left(\mathrm{C}_{3} \mathrm{H}_{8}\right)$} \\
\hline $\mathrm{O}_{2}$ concentration of ambient gas & $21 \%$ & $18 \%$ \\
\hline \hline Fuel flow rate & $20.7 \mathrm{ml} / \mathrm{min}$ & $16.7 \mathrm{ml} / \mathrm{min}$ \\
\hline Average flow velocity of fuel at nozzle exit & $0.0122 \mathrm{~m} / \mathrm{s}$ & $0.0098 \mathrm{~m} / \mathrm{s}$ \\
\hline Reynolds number at nozzle exit & 18.40 & 14.85 \\
\hline
\end{tabular}

Fig. 1 Burner for propane diffusion flame

\section{$2 \cdot 2$ レーザ計測}

図 2 に火炎中の酸素濃度計測に用いたレーザ計測光学系の配置を示す.真空紫外光(波長 $\lambda_{\text {ex: }}$ 193.409nm)を発振で きる Ar-F エキシマレーザ(COMPEX150T, Lambda Physic)を光源とし，平凸レンズ $(f=1000 \mathrm{~mm})$ でレーザ光を集光 し火炎内の測定点に照射した. レーザ光により励起された酸素分子の蛍光をレーザの光軸に対して直角方向に配 置された凸レンズ $(f=150 \mathrm{~mm})$ で集光し, Czerny-Turner type の分光器(250SI, Chromex)に導入した. そして, 分光 器により得られる分光像を ICCD カメラ(Flame star 2, LaVision)で撮影した. カメラとレーザの同期については ICCD カメラ制御ユニットにより制御した. 火炎内酸素濃度の算出には酸素の蛍光強度が酸素濃度と温度に依存 することを利用した手法 ${ }^{(8)}$ を用いた，火炎内の温度については，裸熱電対(Pt-PtRh13\%)を火炎に直接挿入し計測 した．熱電対による火炎内温度の計測では，輻射による測定誤差が懸念される. Sislian ら(9)によって提案された

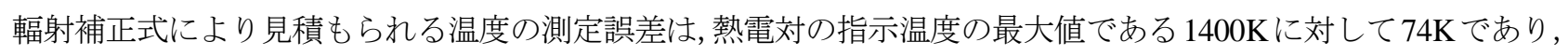
指示温度に対して 5\%程度の誤差を含んでいることになる。 
次に火炎内の寸寸濃度分布計測にはレーザ励起赤熱法(LII 法)を適用した. LII 法に用いた光学系の配置を図 3 に示す. 光源として Kr-F エキシマレーザを用い，レーザ光(波長 $\lambda_{\text {ex }}: 248.469 \mathrm{~nm}$ )をスリットとシリンドリカルレン ズを用いて厚さ $0.5 \mathrm{~mm}$ のシート光を形成し，火炎に照射した。レーザ波長に依存した弾性散乱光をカットするた めのノッチフィルターを配置し, シート光の光軸に対して直角方向から ICCD カメラで火炎内のす寸の赤熱光を 撮影した. 本計測で選定した励起波長では，火炎内に存在する PAHs なども強いレーザ誘起蛍光を発する(10). そ のため，レーザ誘起蛍光とす寸からの赤熱光が畳重することになる．そこで，すすからの赤熱光のみを計測する ため, 時間分解法(10)を適用した. 時間分解法はレーザ誘起蛍光の寿命が赤熱発光より短いことを利用した方法で ある. 具体的な方法については, 佐藤ら ${ }^{(10)}$ の論文に記載されているため, 本論文では割愛する. 以上の処理を行 なうことで, 火炎内の寸寸の赤熱光の二次元分布を計測した. 図 4 に周辺酸素濃度 $21 \%$ と $18 \%$ におけるプロパン 拡散火炎の赤熱発光分布(Soot-LII)を示寸.レーザーシート光の幅が $20 \mathrm{~mm}$ 程度であったため, 図 4 は高さ $L_{f}=30 \mathrm{~mm}$ の火炎に対して火炎上流側と下流側に分割して撮影したものの合成写真である.

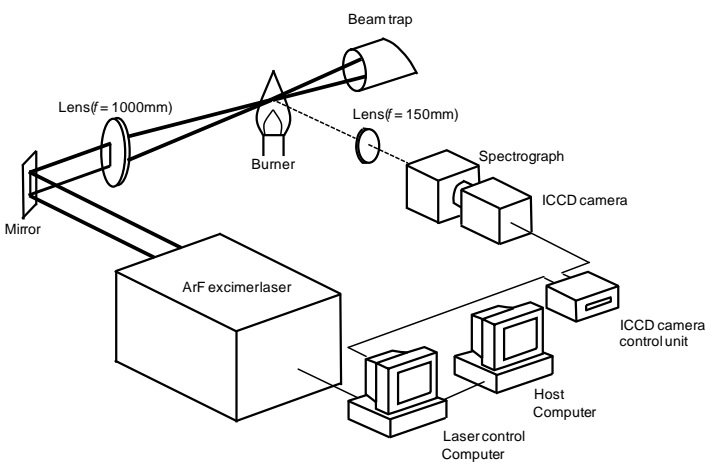

Fig. 2 Optical arrangement for hot $\mathrm{O}_{2}$ LIF measurement

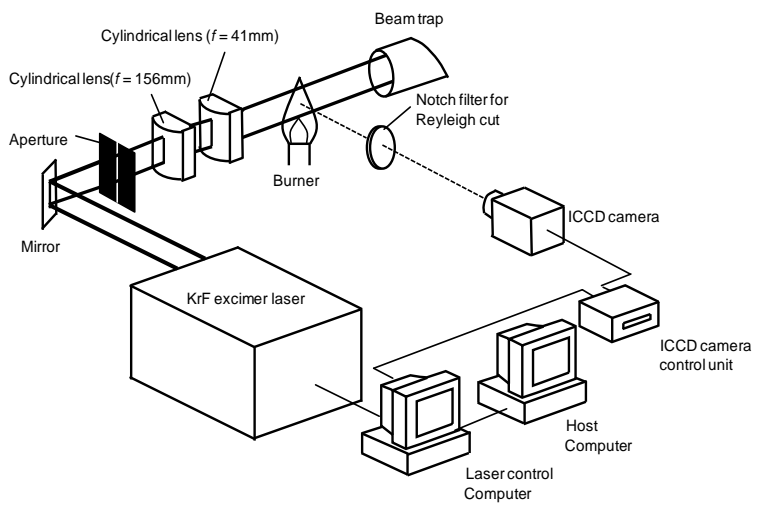

Fig. 3 Optical arrangement for LII measurement

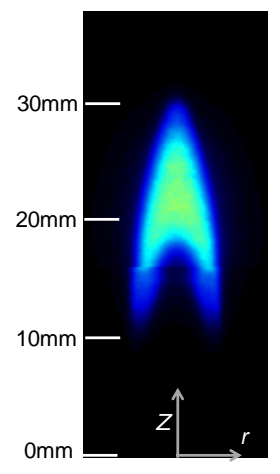

(a) $21 \%$

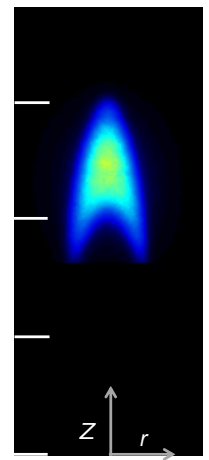

(b) $18 \%$

Fig. 4 LII images

\section{$2 \cdot 3$ 直接サンプリング法}

火炎内に生成される PM 粒径分布と構成成分を分析するため，燃焼ガスを直接サンプリングした．実験装置の概 略を図 5 に示寸．ここでは，内径 $0.9 \mathrm{~mm}$ ，外径 $1.4 \mathrm{~mm}$ のステンレス製プローブを火炎内に挿入し，シリンジを用い て火炎内の燃焼生成物を含んだ然焼ガスをサンプリングした．ここで，サンプリング法により火炎内の燃焼生成物 を捕集する場合，サンプリングプローブ内での燃焼反応の進行が䀣念される．この点について，過去に行なった著 者ら ${ }^{(8)}$ の結果から, 火炎内の酸素濃度についてサンプリング法と光学的手法(LIF 法)から得られた結果を比較したと ころ大きな差異は認められなかった. これはプローブ内では酸素を消費するような燃焼反応が起きていないことを 意味している.燃焼ガスの吸引速度は, 吸引による火炎への乱れを防ぐために火炎内の燃焼ガス速度と等しくした. 粒径分布計測では，シリンジにより採取した燃焼ガス中のPM SMPS（Model 3034, TSI 社）により計測した.ま 
た，火炎から排出された燃焼ガスを火炎先端の直上に設置したプローブにより全量吸引し，石英フィルタで然焼ガ ス内の PM を捕集した．そして超微量 PM 分析装置(MEXA-1370PM，HORIBA 社) により，PM の成分分析を行っ た.

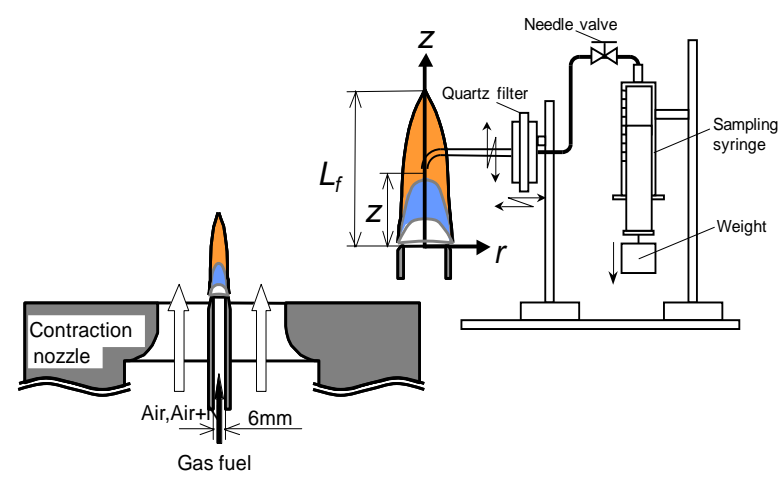

Fig. 5 Soot sampling system

\section{3. 実験結果}

\section{$3 \cdot 1$ すすの赤熱発光と酸素濃度との関係}

火炎の中心軸上におけるす寸粒子の赤熱発光強度と酸素濃度の分布を図 6 に示寸. 図 6(a)が火炎の周辺酸素濃度が $21 \% の$ 場合，(b)が 18\%の場合である. また，図6(c)に雰囲気酸素濃度 18\%における火炎形状の違いによる火炎内酸素濃度と赤熱 発光強度分布を示寸. 図中の第 2 軸 (右側の縦軸)は, 寸寸粒子の赤熱発光強度の最大值で正規化した值である. 周辺酸素 濃度 $18 \%$ では $Z=5 \mathrm{~mm}$ の結果が示されていないが，これは然料のプロパンが $21 \%$ と比較してより下流まで存在し，プロパ ンの蛍光波長が $\mathrm{Hot}_{2}$ の蛍光波長と一致していて，両者の蛍光を分離することができなかったためである.

雰囲気酸素濃度 $21 \%$ の場合(図 6(a)), 噴孔から $10 \mathrm{~mm}$ の位置で赤熱発光が検出され, 火炎内です寸が生成され始めたこと を示している. 噴孔から $20 \mathrm{~mm}$ です寸の生成量がピークとなり，その後，す寸が減少し火炎先端付近では，検出できなく なった. 火炎内の酸素濃度については，噴孔から下流に向かうにつれて酸素濃度が増加した. しかし， $Z=20 \mathrm{~mm}$ の位置か ら下流に向かうにつれて火炎内酸素濃度が減少した. 最初の酸素濃度の上昇は火炎基部から流入した酸素が火炎の中心軸ま で拡散してきたことを示している. $Z=20 \mathrm{~mm}$ の位置からの酸素濃度の減少は寸寸の赤熱発光強度の減少傾向と一致してい るので, 寸寸の燃焼のために火炎内の酸素が消費されたと考えられる. 噴孔から $27 \mathrm{~mm}$ の位置からは酸素濃度が再度上昇 している. これは，周囲からの拡散て導入される酸素は火炎長とともに減少寸る傾向にあるが， $Z=20 \mathrm{~mm}$ 以降ではす寸の 絶対量が少なくなりす寸の酸化で消費される酸素より周囲からの拡散で補われる酸素の方が上回っているためと考えられ る.

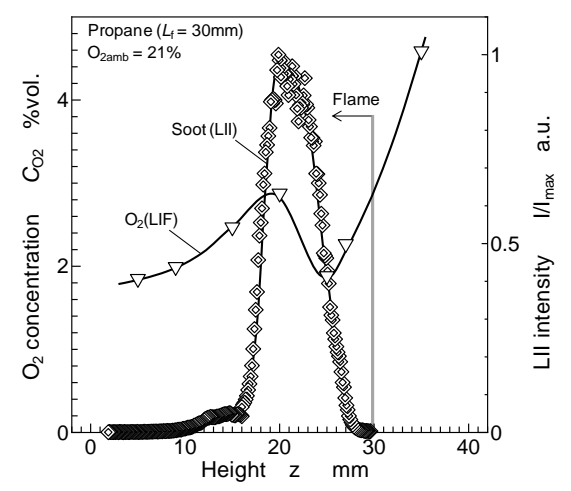

(a) $21 \%\left(L_{f}=30 \mathrm{~mm}\right)$

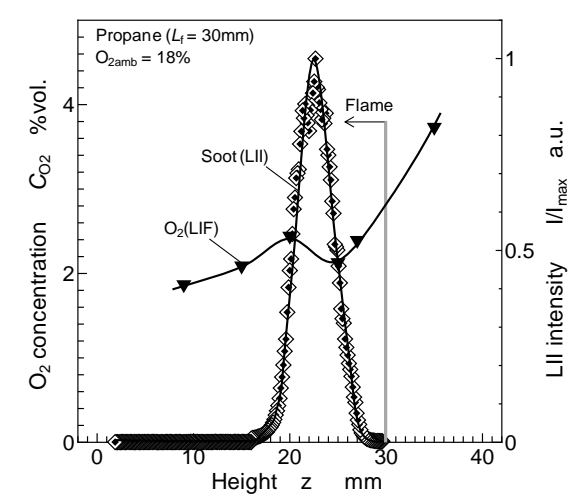

(b) $18 \%\left(L_{f}=30 \mathrm{~mm}\right)$

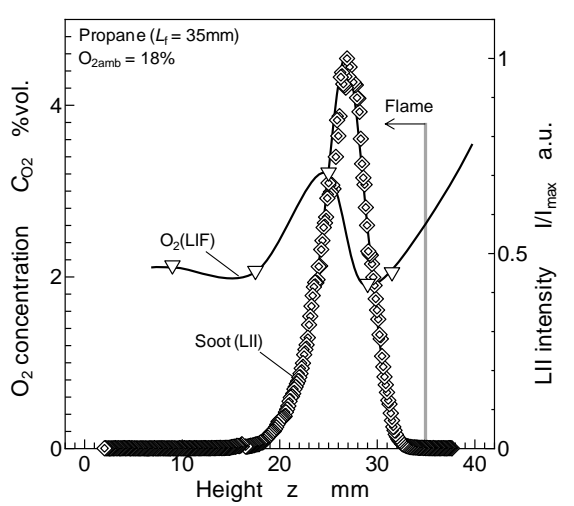

(c) $18 \%\left(L_{f}=35 \mathrm{~mm}\right)$

Fig. 6 Relationship between $\mathrm{O}_{2}$ concentration and LII intensity 
次に雾囲気酸素濃度 $18 \%$ の場合(図 6(b))では, 寸寸の赤熱発光が噴孔から $16 \mathrm{~mm}$ 程度の位置から検出され始め, 雰囲気酸 素濃度 $21 \%$ 火炎に比べより下流側です寸の生成が開始されていた．これは，雰囲気酸素濃度 $18 \%$ では周囲と火炎内の酸 素濃度の勾配が小さく, 火炎内一の酸素の拡散が緩慢となりす寸生成の前駆物質となる PAHs などの生成反応が緩慢になつ たためと考えられる. また，生成されたす寸のピーク位置も雾囲気酸素濃度 $21 \%$ 火炎に対して下流側に移行した. 火炎 内酸素濃度については, 雾囲気酸素濃度 $21 \%$ の炎と同様に噴孔から $Z=20 \mathrm{~mm}$ 付近までは増加した. しかし雰囲気酸素濃 度 $21 \%$ の場合と比べ $Z=20 \mathrm{~mm}$ のピーク値は低くなった. 噴孔から $20 \mathrm{~mm}$ の位置より下流では, 火炎内酸素濃度が減少し火 炎先端付近 $(Z=27 \mathrm{~mm})$ から増加した。 ここで, $Z=20 \mathrm{~mm}$ から $27 \mathrm{~mm}$ における火炎内酸素濃度の減少割合が，雾囲気酸素濃 度 $21 \%$ 炎に対して, 雰囲気酸素濃度 $18 \%$ のほうが小さいことがわかる.これは, 表 1 に示すように䨌囲気酸素濃度 $18 \%$ の火炎では燃料流量が $21 \%$ の炎に対して少なく火炎内で生成されるす寸が少ないため，才寸の燃焼に消費される火炎内 の酸素も少ないためと考えられる. 寸寸が生成され始める火炎内酸素濃度に着目寸ると, 雾囲気酸素濃度と火炎形状に依ら

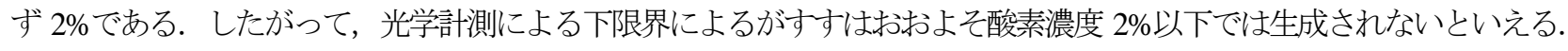
これはプロパン由来のPAHから最終的にす寸となるためには, PAHから水素を引き抜く脱水素反忘に必要な酸素が濃度と して2\%以上必要であることを意味している。

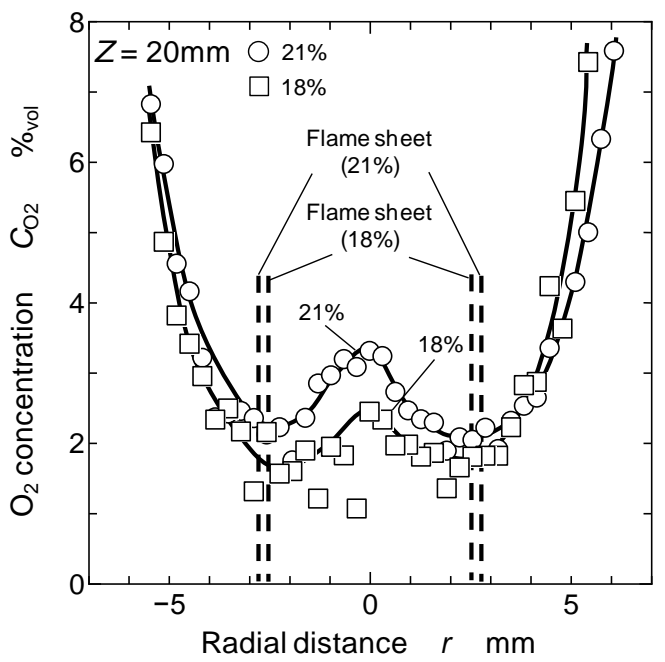

Fig. $7 \mathrm{O}_{2}$ concentration distribution in flames on radial axis

次に火炎中心軸上で火炎内酸素濃度がピーク值を示す $Z=20 \mathrm{~mm}$ における火炎内酸素濃度の半径方向分布を図 7 に示寸. 目視で確認できる火炎と雾囲気の境界を破線で図中に示した. 半径方向の酸素濃度は雾囲気の酸素濃度が火炎中心に向かう につれて減少し, 雰囲気と火炎との境界付近で最少となった. 更にその境界から火炎中心に向かうにつれて酸素濃度が増加 した. 図6で述べたように噴孔から Z=20mm に向かうにつれて火炎中心軸上の酸素濃度が増加したことを考慮すると，こ れは火炎の根元および上流の火炎帯から中心部に向かって拡散した酸素が火炎内で消費されずに残っていることを意味し ている.

図 8 に赤熱発光強度と火炎内の温度との比較を示す。図 8 から雰囲気酸素濃度に依らす噴孔から下流に向かうにつれて 温度は上昇し, 火炎先端付近 $(Z=27 \mathrm{~mm})$ で温度が下降に転じた. 火炎内温度に着目寸ると赤熱発光強度が減少に転じる位置 $(21 \%: Z=20 \mathrm{~mm}, 18 \%: Z=23 \mathrm{~mm})$ で, 温度が急激に上昇する傾向がみられる. これは, 寸寸の燃焼による発熱が原因と考え られる. さらに, 図6の火炎内酸素濃度の分布と比較すると, 温度が下降に転じる位置と酸素濃度が増加する位置が一致し た. これはす寸などのPM が下流に向かうにつれて減り燃焼が緩慢になったことで火炎内温度が低下し, 雾囲気から拡散に より導入される酸素が燃焼により消費される酸素を上回るためと考えられる. 


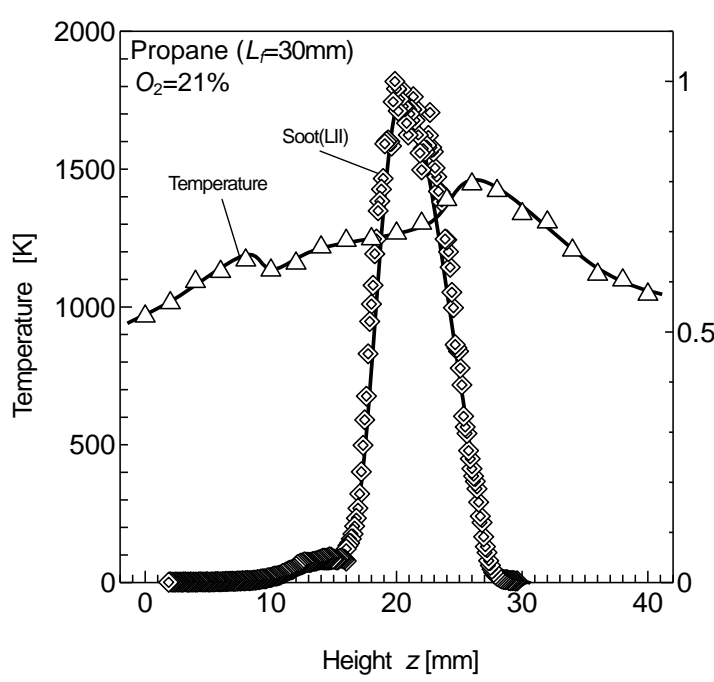

(a) $21 \%$

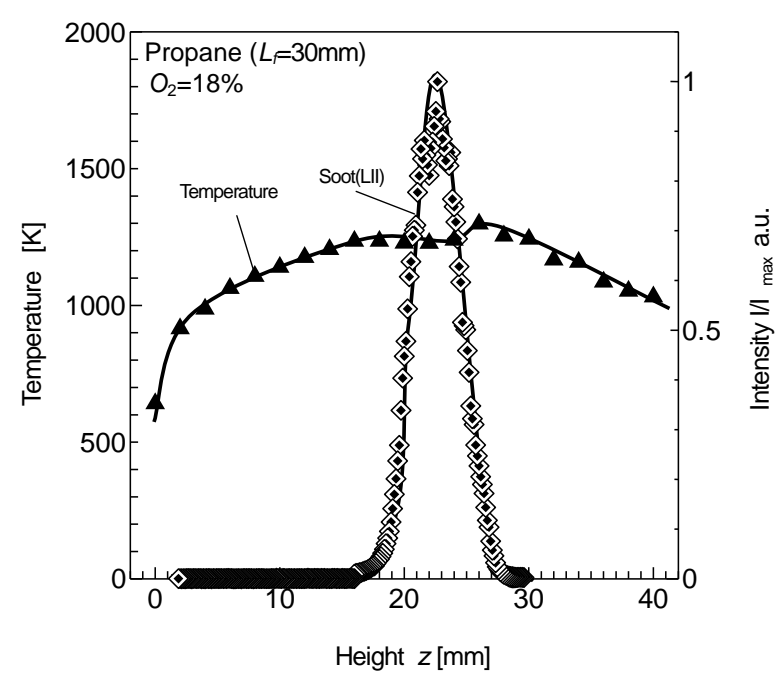

(b) $18 \%$

Fig. 8 Relationship between temperature and ILL signal

\section{3 ・ 雰囲気酸素濃度による火炎内で生成されるPM 特性に与える影響}

図 9 に周辺雰囲気酸素濃度 $21 \%$ における火炎内で生成される PM 粒径分布を示す． $Z=9 \mathrm{~mm}$ では，PM 径が $30 \mathrm{~nm}$ 程度の ところで個数濃度がピークを示す分布となった. ここで図6(a)のすすの赤熱発光強度と比較すると $Z=9 \mathrm{~mm}$ ではすすの赤熱 発光は検出されていない.このことを考慮すると $Z=9 \mathrm{~mm}$ で検出された $\mathrm{PM}$ は固体のすすで構成される $\mathrm{PM}$ ではないと考え られる. $Z=9 \mathrm{~mm}$ から $Z=20 \mathrm{~mm}$ に向かうにつれて個数濃度のピークが大粒径側に移行し PM個数濃度も増加した. 図 6 (a)より $Z=9 \mathrm{~mm}$ では赤熱発光が検出されず $Z=15 \mathrm{~mm}$ から $20 \mathrm{~mm}$ では検出され，さらに発光強度が増加していることから， 大粒径側のPM は固体のす寸により構成されていると考えられる. 次に, $Z=20 \mathrm{~mm}$ より下流側 $(Z=25 \mathrm{~mm}, 27 \mathrm{~mm})$ に着目 寸ると大粒径側のPM の個数濃度が減少していることがわかる. 個数濃度で $1 / 10$ 程度の減少であるが, 体積に換算すると相 当量の PM が減少したことになる. ここで, 図 6(a)の $Z=20 \mathrm{~mm}$ より下流の領域に着目すると, 前述したように火炎内酸素 濃度とすすの赤熱発光強度が同時に減少しているので, この領域ではすすで構成される PMが然焼したためにPM個数濃度 が減少したと考えられる. また， $Z=25 \mathrm{~mm}$ から $27 \mathrm{~mm}$ における大粒径側の個数密度はほぼ同じであるが，その要因につい ては不明である.

図 10 にPM 個数濃度について䨌囲気酸素濃度による比較を示す。火炎内 $(Z=9 \mathrm{~mm}, 20 \mathrm{~mm}, 25 \mathrm{~mm})$ では周囲酸素濃度 $18 \%$

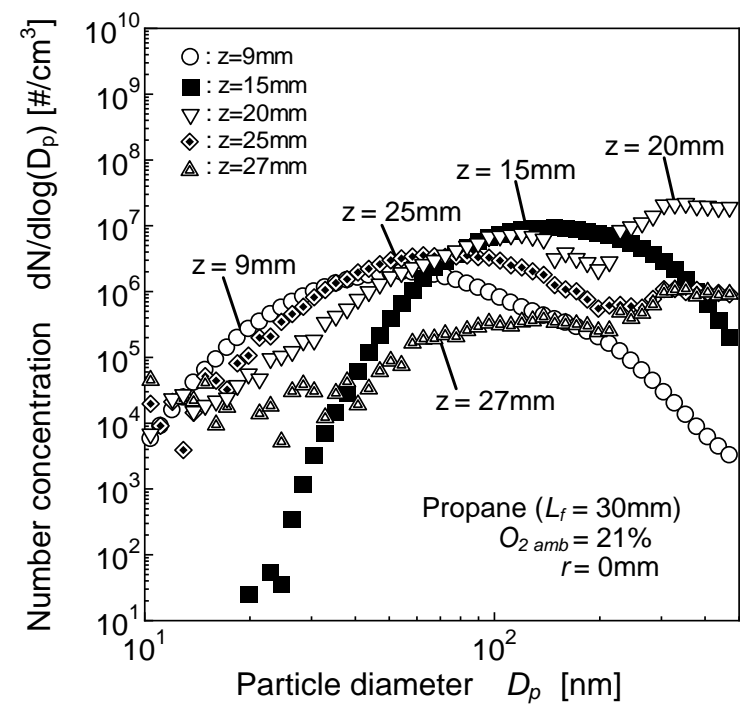

Fig. 9 PM size distribution 


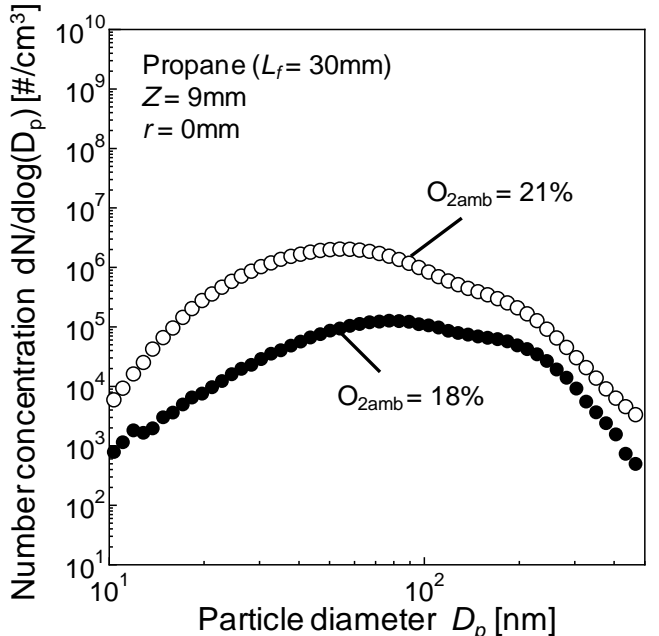

(a) $Z=9 \mathrm{~mm}$

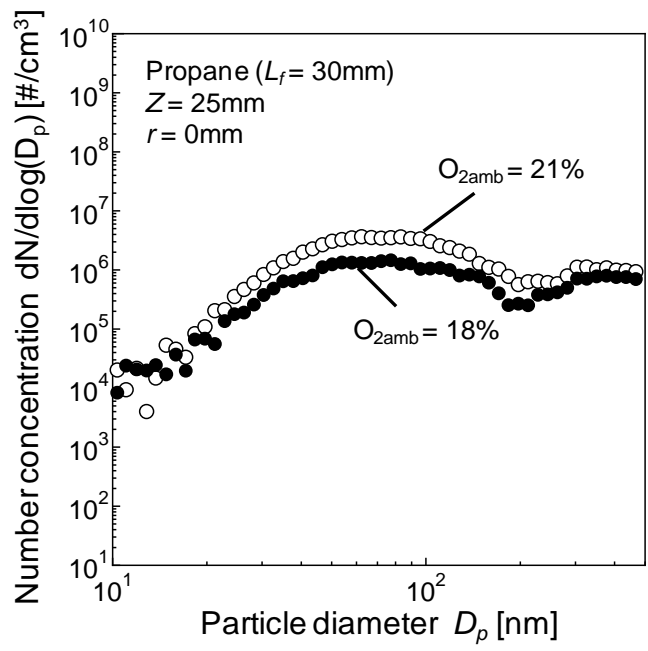

(c) $Z=25 \mathrm{~mm}$

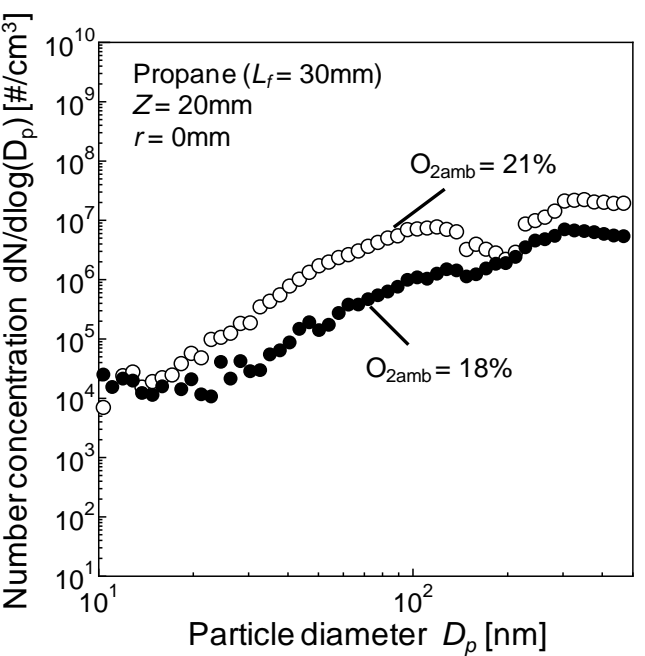

(b) $Z=20 \mathrm{~mm}$

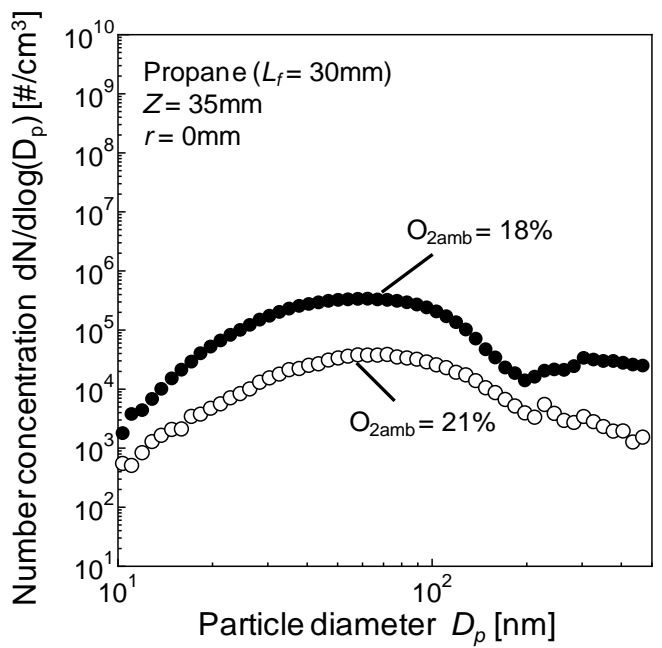

(d) $Z=35 \mathrm{~mm}$

Fig. 10 Comparison of PM size distributions with different $\mathrm{O}_{2}$ concentrations

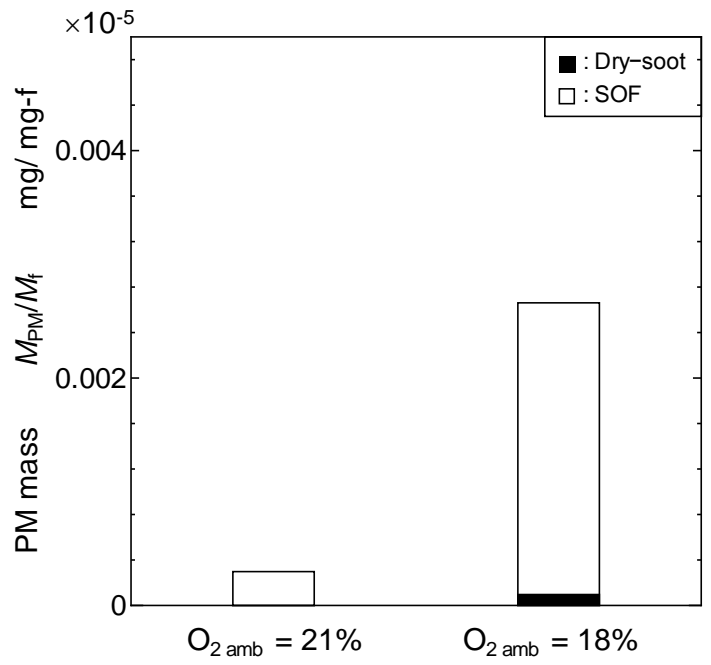

Fig. 11 PM compositions 
18\%では，火炎内での燃焼反応が緩曼になり同じ火炎高さで個数濃度を比較すると $18 \%$ は21\%に対して一次粒子の生成が 遅れ, 個数濃度が低くなったと考えられる. 火炎の上流から下流に向かうにつれて, 個数濃度の周辺酸素濃度による差が なくなり, 火炎外である Z=35mm では雰囲気酸素濃度 $21 \%$ PM 個数濃度が $18 \%$ の場合より低くなり, 火炎内の傾向に対 して逆転が生じた.

ここで, 火炎先端より下流域(Z=35mm)における PM 構成成分を図 11 に示寸. 縦軸は単位然料質量あたりのPM構成成分 の質量である. 周辺酸素濃度 $18 \%$ の場合, PM 総質量が $21 \%$ に対して多く, 図 10(d)からも周辺酸素濃度 $18 \%$ の個数濃度が $21 \%$ と比べて多くなっている. またPM 構成成分に着目すると周辺酸素濃度に依らずSOF を主体としているが，周辺酸素 濃度 $18 \%$ の場合, Dry-soot も含まれている. 図 11 は周辺酸素濃度 $21 \%$ 炎炎に対し $18 \%$ 炎は, 燃料流量が少ないにも

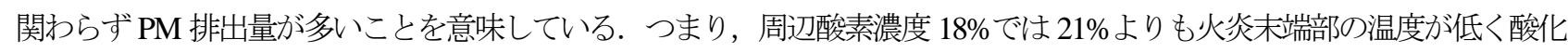
が起きにくいため，す寸に成長しきれなかった未燃成分である PAH と未酸化の寸寸( Dry-soot)で構成される PM が $21 \%$ 比べて多く排出されたと考えられる.

\section{4 結 言}

層流拡散火炎内の酸素濃度，才寸濃度，およびPMの粒径分布計測を行なった結果，以下の知見を得た.

1. 雾囲気空気流および拡散により火炎面に運ばれた酸素は火炎面で完全に消費されずに，火炎中心軸に到達する.

2. 火炎内の酸素濃度がおおよそ $2 \%$ 以下では火炎内です寸が生成されない.

3. 火炎下流では，火炎内の酸素がす寸の燃焼に消費される.

4. 火炎内の PM 個数濃度は, 周辺酸素濃度 $21 \%$ の方が $18 \%$ と比べて高いが, 噴孔から下流に進むにつれて, 周辺酸素濃 度の違いによる個数濃度の差が小さくなった，さらに，火炎外では周辺酸素濃度 $21 \%$ PM 個数濃度が $18 \%$ と比較し て低くなった.

5. 火炎外では周囲酸素濃度の低い方が PM 排出量が多く, 排出される PM の主成分はSOFである.

\section{文献}

(1) Kittelson, D., Jhonson, J., Wattts, W., Qiang, W., Paulsen, D., and Bukowiecki, N., "Diesel Aerosol Sampling in the Atomosphere", SAE TECHNICAL PAPERS, (2000), 2000-01-2212.

（2）新岡 嵩, 河野通方, 佐藤順一, 燃焼現象の基礎，(2001），オーム社.

(3) Tuji, H. and Yamamoto, I., "The structure of counterflow diffusion flames in the forward stagnation region of a porous cylinder", Proceedings of 12th symposium on combustion,Vol.11, Issue 1 (1967) p.997-1005.

(4) 長谷川義朗, 中村祐二, 山下博史, “対向流拡散火炎中の PAHs 生成に与える酸素濃度の影響”, 日本機械学会 論文集 B 編，Vol.71，No.705 (2005) pp.1475-1482.

(5) Xu, F., El-Leathy, A. M., Kim, C. H. and Faeth, G. M., "Soot surface oxidation in hydrocarbon/air diffusion flames at atmospheric pressure", Combustion and flame, Vol.132 (2003) pp.43-57.

（6）林田和宏，天谷賢児，新井雅隆，“ $\mathrm{KrF}$ エキシマレーザを用いたレーザ誘起蛍光法によるプロパン拡散火炎内 の OH 計測”，日本機械学会論文集 B 編，Vol.65, No.633 (1999) pp.1793-1799.

（7）林田和宏，天谷賢児，新井雅隆，“レーザ誘起蛍光法による触媒燃焼ガス中の NO 濃度計測”，日本機械学会論 文集 B 編，Vol.68，No.674 (2002) pp.2914-2919.

（8）座間淑夫，北爪真奈美，古畑朋彦，新井雅隆，“レーザ誘起蛍光法による層流拡散火炎内の酸素濃度計測”，日 本機械学会論文集 B 編, Vol.78, No.787 (2012) pp.644-651.

(9) Sislian, J. P., Jiang, L.Y. and Cusworth, R.A., "Laser doppler velocimetry investigation of the turbulence structure of axisymmetric diffusion flames", Progress in Energy and Combustion Science, Vol.14, No. 2(1988), pp.99-146.

（10）佐藤桂司，林田和宏，天谷賢児，新井雅隆，“火炎中に生成される多環芳香族炭化水素のレーザ計測 (第 1 報, 時 間分解計測によるレーザ誘起蛍光と赤熱発光の分離)”, 日本機械学会論文集 B 編, Vol.70, No.692 (2004) pp.1051-1057. 